НАУКОВИЙ ВІСНИК

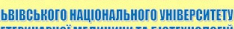
entific veminc messenger of Liviv National University of
veterinary Medicine and Biotechnologies

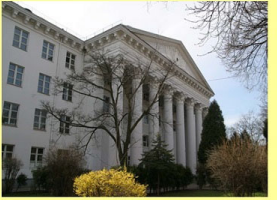

СЕРИЯ "ЕКОНОМІЧНІ НАУКИ"

Том 22 № 95 2020
Науковий вісник Аьвівського національного університету ветеринарної медицини та біотехнологій імені С.3. Гжицького. Серія: Економічні науки

\author{
Scientific Messenger of Lviv National University \\ of Veterinary Medicine and Biotechnologies. \\ Series: Economical Sciences
}

ISSN 2519-2701 print

https://nvlvet.com.ua/index.php/economy

doi: 10.32718/nvlvet-e9503

UDC 338.4(477)

\title{
Economic prerequisite of milk production growth in Ukraine
}

\author{
V. Chemerys, V. Dushka, V. Maksym, M. Dorosh-Kizym \\ Stepan Gzhytskyi National University of Veterinary Medicine and Biotechnologies Lviv, Ukraine
}

Article info

Received 01.09.2020

Received in revised form 01.10 .2020

Accepted 02.10.2020

Stepan Gzhytskyi National University of Veterinary Medicine and Biotechnologies Lviv,

Pekarska Str., 50, Lviv, 79010, Ukraine.

Tel.: +38-097-58-701-77

E-mail: volodiamaxym88@gmail.com
Chemerys, V., Dushka, V., Maksym, V., \& Dorosh-Kizym, M. (2020). Economic prerequisite of milk production growth in Ukraine. Scientific Messenger of Lviv National University of Veterinary Medicine and Biotechnologies. Series: Economical Sciences, 22(95), 15-21. doi: 10.32718/nvlvete9503

In the article the resulted research, on the basis of which certainly and grounded basic economic prerequisite of milk production growth in Ukraine. Also investigational dynamics of quantity of cows in the economies of all categories and basic structural tendencies are set. Grounded descending dynamics of milk production, in particular in the households. Investigational balance of production of milk and dairy products in Ukraine during 2010-2020 years. It is set that one of principal reasons of negative tendencies, which take place in the suckling cattle breeding of Ukraine there is absence the economic stimulus of milk production and capital investments through the low level of purchase prices from the households, which does not cover incurred charges by them. It is offered as a result of research, that dairy farming development it is necessary to provide realization of complex organizational and economic measures, related to optimization of distribution internal fields profit, which is formed in dairy production complex, by establishment of the grounded purchase prices on milk from the households. The minimum standard of purchase prices is expected for the households, which will defray costs production and provide the receipt of level of profitability, which will stimulate maintenance of cows herd in economies. Development of the system of deliberative services is also offered, in particular informative providing of subjects of manage in dairy farming. Grounded introduction of vertical diversification for the milk producers in Ukraine, by deepening the processing of raw material on eventual commodities and network development sales on local markets, with the purpose of achievement of higher level influence on forming the last bid on dairy products. Also in the article the use of the specialized investment funds is offered in relation to bringing in financial resources in the dairy farming with application of comfortable for potential investors on-line of platforms and informative resources.

Key words: milk, dairy farming, price, enterprise, households, optimization, production.

\section{Економічні передумови зростання виробництва молока в Україні}

\author{
В. Чемерис, В. Душка, В. Максим, М. Дорош-Кізим
}

Львівський національний університет ветеринарної медицини та біотехнологій імені С. 3. Гљсицкого, м. Львів, Україна

У статті наведені результати дослідження, на основі яких визначено та обтрунтовано основні економічні передумови зростання виробництва молока в Україні. Також досліджено динаміку чисельності корів у господарствах усіх категорій та встановлено основні структурні тендениї. Обтрунтовано спадну динаміку виробництва молока, зокрема у господарствах населення. Досліджено баланс виробництва молока та молокопродуктів в Україні за 2010-2020 рр. Встановлено, щзо однією з основних причин негативних тендениій, які відбуваються у молочному скотарстві Украйни є відсутність економічних стимулів виробництва молока та капітальних інвестицій через низький рівень закупівельних иін на молоко від господарств населення, який не покриває понесені ними витрати. За результатами дослідження запропоновано, що для розвитку молочного скотарства необхідно забезпечити реалізацію комплексу організаційно-економічних заходів, пов'язаних з оптимізацією розподілу внутрішньогалузевого прибутку, який формується в молокопродуктовому підкомплексі, иляхом встановлення обтрунтованих закупівельних иін на молоко від господарств населення. Розраховано мінімальний рівень закупівельних иін для господарств населення, який покриватиме витрати виробництва та забезпечить одержання рівня прибутковості, який стимулюватиме утримання поголів'я корів у господарствах. Та- 
кож запропоновано розвиток системи дорадчих послуг, зокрема інформаційного забезпечення суб'єктів господарювання у молочному скотарстві. Обтрунтовано впровадження вертикальної диверсифікації для виробників молока України, иляхом поглиблення переробки сировини на кінцеві товари та розвитку мереж продажу на місцевих ринках, з метою досягнення вищого рівня впливу на формування кінцевої иіни на молокопродукти. Також у статті запропоновано використання спеціалізованих інвестиційних фондів щуодо залучення фінансових ресурсів у молочне скотарство із застосуванням зручних для потенційних інвесторів онлайн платформ та інформачійних ресурсів.

Ключові слова: молоко, молочне скотарство, ціна, підприємство, господарства населення, оптимізація, виробництво.

\section{Вступ}

Актуальність теми. Молочне скотарство відноситься до одних 3 основних напрямів тваринництва, що забезпечує населення цінною продовольчою продукцією, а переробні підприємства сировиною для виробництва молокопродуктів, від яких залежить рівень продовольчої безпеки держави. Однак, уже десятки років виробництво молока невпинно зменшується 3 одночасним скороченням поголів'я корів, що негативно позначається на економічному потенціалі молочного скотарства України. Скорочення кількості корів у господарствах усіх категорій, а з ним і падіння обсягів виробництва молока $є$ наслідком несприятливих економічних та соціальних чинників, які виникли та набули значної вагомості впливу іще на початку становлення незалежності держави. Проблемам розвитку молочного скотарства в Україні присвячені праці багатьох вітчизняних науковців, зокрема: Л. Воляк (Voliak \& Halitska, 2018), В. Колоша (Kolosha, 2018), B. Poccoxa (Rossokha \& Petrychenko, 2018), С. Самайчук (Samaichuk, 2020), О. Чередніченко, О. Пащенко (Cherednichenko \& Pashchenko, 2018) та інші. Дослідження щодо розвитку виробництва молока часто зустрічаються у працях зарубіжних науковців: A. Parzonko, P. Bórawski (Parzonko \& Bórawski, 2020), M. Michaličková, Z. Krupová, P. Polák, L. Hetényi, E. Krupa (Michaličková et al., 2014), P. Kopeček (Kopeček, 2002), S. Pieralli, S. Hüttel, M. Odening (Pieralli et al., 2017), J. Sauer, U. LataczLohmann (Sauer \& Latacz-Lohmann, 2015) та інших.

Також розроблено та затверджено значну кількість програм розвитку та державної підтримки тваринництва, зокрема і молочного скотарства. Однак, враховуючи щорічну спадну динаміку виробництва молока та чисельності корів у господарствах, проведення наукових досліджень щодо удосконалення існуючого господарського механізму стимулювання розвитку молочного скотарства в Україні, залишаються актуальними та необхідними.

Однією з основних задач сільського господарства країни є забезпечення іiї продовольчої безпеки. Молочне скотарство $є$ основною ланкою молокопродуктового підкомплексу, ефективне функціонування якого переважно визначається рівнем розвитку виробництва в даній галузі (Samaychuk, 2020). Розвиток молочної галузі України потребує науково обгрунтованого регулювання ринку продуктів споживання, скорочення витрат виробництва. Особлива роль належить ціновому регулюванню, яке має сприяти виробництву необхідної кількості продуктів відповідно до раціональних норм споживання та захищати вітчизняних товаровиробників від насичення ринку імпортною продукцією. Особливу увагу заслуговує питання державного регу- лювання ринку молока, спрямоване на заохочення фермерів займатися його виробництвом і входити на ринок (Cherednichenko \& Pashchenko, 2018).

У сучасних умовах досліджувана галузь, незважаючи на окремі позитивні тенденції, продовжує перебувати в складному становищі. Це пов'язано з відносно низьким рівнем прибутковості виробництва молока і водночас високим рівнем капіталомісткості його виробництва. Саме збитковість галузі скотарства протягом значного періоду часу $є$ одним з головних факторів скорочення як поголів'я, так і обсягів виробництва молока (Kolosha, 2018). Для подолання цієї кризи необхідно проаналізувати сучасний стан виробництва та реалізації молочної продукції, виявити причини негативних явищ та надати рекомендації щодо подальшого розвитку (Voliak \& Halitska, 2018).

Мета $і$ завдання дослідження полягає у визначені та обгрунтуванні основних економічних передумов, які забезпечать зростання виробництва молока в Україні. Для досягнення поставленої мети необхідно дослідити стан галузі молочного скотарства в Україні; провести аналіз основних показників росту та оцінити їх тенденцію; визначити та обгрунтувати основні економічні умови зростання у молочному скотарстві.

\section{Матеріал і методи досліджень}

У дослідженні економічних передумов зростання виробництва молока в Україні використанні загальнонаукові методи дослідження серед яких: монографічний метод, при комплексному дослідженні проблем розвитку молочного скотарства в Україні, аналіз та синтез, при визначенні та виокремлені складових, чинників зростання у молочному скотарстві на основі дослідження статистичних даних; розрахунковоконструктивний метод - для обгрунтування запропонованих заходів, які сприятимуть формуванню необхідних економічних передумов зростання виробництва молока в Україні.

\section{Результати та їх обговорення}

Станом на 1 січня 2020 рокі в Україні налічується понад 3 млн. голів ВРХ, у тому числі 1,78 млн корів. Поголів'я телиць від 1 до 2 рокі становило 288 тис. голів. За співвідношенням чисельності телиць старшої вікової групи та корів можливо визначити приблизний термін експлуатації корів, який в середньому становить 6,2 роки у господарствах усіх категорій. Проте у агропідприємствах період використання корів помітно коротший та становить близько 3 років. У господарствах населення даний показник становить близько 10 років. 
За досліджуваний період спостерігається швидке скорочення поголів'я корів у господарствах усіх категорій. Так, за 10 років чисельність корів скоротилася у 2,8 раза, зокрема найбільш активне скорочення відбулося у агропідприємствах - 4,2 раза. При цьому у господарствах населення чисельність корів скоротилася у 2,3 раза. Станом на 2020 р. темп скорочення чисельності корів по відношенню до попереднього року становив 7\%, а середньорічні темпи скорочення поголів'я корів за 5 років досягли 10 пунктів.

Втрата інтересу до утримання корів в усіх категоріях господарств зумовлена щорічним подорожчанням кормів, енергоносіїв, ветпрепаратів, засобів гігієни, недосконалістю механізму дотування сільськогосподарських товаровиробників та низьким рівнем державної підтримки молочного тваринництва (Rossokha \& Petrychenko, 2018).

\section{Таблиця 1}

Розподіл сільськогосподарських тварин за статевовіковими групами (станом на 1 січня)

\begin{tabular}{lcccccc}
\cline { 2 - 6 } & 2015 & 2017 & 2018 & 2019 & 2020 & 2020 р. до 2015 р., \% \\
\hline Господарства усіх категорій (100 \%) & 2262,7 & 2108,9 & 2017,8 & 1919,4 & 1788,5 & 79,0 \\
Сільськогосподарські підприємства (24,5\%корови) & 529,2 & 484,6 & 466,6 & 467,8 & 438,6 & 82,9 \\
Господарства населення (75,5\%корови) & 1733,5 & 1624,3 & 1551,2 & 1451,6 & 1349,9 & 77,9 \\
\hline
\end{tabular}

Джерело: складено на основі http://www.ukrstat.gov.ua

В Україні майже 1,9 тис. підприємств, які утримують корів. Більшість із них відносяться до малих 3 чисельністю до 100 корів і лише 3,4 \% - крупні підприємства, які утримують понад 1000 корів. Загалом у великих господарствах сконцентровано близько чверті усіх корів (табл. 2).
В період 32010 р. до 2020 р. виробництво молока загалом зменшилося на 14 \%. Зменшення відбулося за рахунок господарств населення, а в підприємствах, за аналогічний період, обсяги виробництва зросли на $24 \%$, що пояснюється зростанням середньорічних надоїв молока на корову.

\section{Таблиця 2}

Групування підприємств за кількістю сільськогосподарських тварин (станом на 01 січня 2020 року)

\begin{tabular}{lcccc}
\hline \multirow{2}{*}{ Підприємства 3 } & \multicolumn{2}{c}{ Кількість підприємств } & \multicolumn{2}{c}{ Кількість тварин } \\
\cline { 2 - 5 } чисельністю поголів’я & Од. & у \% до загальної кількості & Од. & у \% до загальної кількості \\
\cline { 2 - 5 } & 1894 & 100,0 & 438,6 & 100,0 \\
\hline до 50 & 625 & 33,0 & 10,1 & 2,3 \\
$50-99$ & 228 & 12,0 & 16,5 & 43,8 \\
$100-499$ & 801 & 42,3 & 191,5 & 26,6 \\
$500-999$ & 175 & 9,3 & 116,9 & 23,6 \\
більше 1000 & 65 & 3,4 & 103,6 & \\
\hline
\end{tabular}

Джерело: складено на основі http://www.ukrstat.gov.ua

Також варто зазначити про дворазове зростання виробництва молока за 2010-2020 pр. у фермерських господарствах. Однак вагомість впливу фермерських господарств на пропозицію молока залишається низькою, оскільки на них припадає лише 2 \% від сумарно- го обсягу виробленої продукції. Найбільша частка молока виробляється господарствами населення понад 70 \% станом на 2020 р., що на 10 процентних пунктів менше ніж на початку 2010 р.

\section{Таблиця 3}

Виробництво молока в Україні за 2010-2019 рр., тис. т

\begin{tabular}{lcccccc}
\cline { 2 - 5 } & \multicolumn{3}{c}{ Рік } & \multicolumn{2}{c}{$2019 \mathrm{p}}$. \\
\cline { 2 - 5 } & 2010 & 2015 & 2017 & 2018 & 2019 & до 2017 p., \% \\
\hline Господарства усіх категорій & 11248,5 & 10615,4 & 10280,5 & 10064,0 & 9663,2 & 94,0 \\
Сільськогосподарські підприємства & 2216,6 & 2669,2 & 2765,7 & 2755,5 & 2728,6 & 98,7 \\
$\quad$ у тому числі фермерські господарства & 112,1 & 177,4 & 194,8 & 201,8 & 209,2 & 107,4 \\
Господарства населення & 9031,9 & 7946,2 & 7514,8 & 7308,5 & 6934,6 & 92,3 \\
\hline
\end{tabular}

Джерело: складено на основі http://www.ukrstat.gov.ua

Середній річний надій молока від однієї корови за 10 років виріс більше ніж у два рази в господарствах усіх категорій, що частково стримувало темпи зменшення виробництва. Станом на 2020 рік в середньому від однієї корови одержують до 5000 кг молока. Найбільше зростання молочної продуктивності корів відбулося у агропідприємствах. За 2010-2020 рр. на- дій молока на корову у підприємствах виріс більше ніж у двічі, однак продовжує залишатися на відносно низькому рівні, якщо порівнювати 3 показниками багатьох держав із розвинутим високотехнологічним молочним скотарством. Загалом річні надої на корову у підприємствах на $25 \%$ вищі ніж у господарствах населення. 
Таблиця 4

Середній річний надій молока від однієї корови за 2000-2019 рр.

\begin{tabular}{|c|c|c|c|c|c|c|}
\hline & \multicolumn{5}{|c|}{ Рік } & \multirow{2}{*}{2019 р. до 2017 р., \% } \\
\hline & 2000 & 2015 & 2017 & 2018 & 2019 & \\
\hline Господарства усіх категорій & 2359 & 4644 & 4820 & 4922 & 4976 & 103,2 \\
\hline Сільськогосподарські підприємства & 1588 & 5352 & 6025 & 6190 & 6101 & 101,3 \\
\hline Господарства населення & 2960 & 4437 & 4480 & 4559 & 4630 & 103,3 \\
\hline
\end{tabular}

Джерело: складено на основі http://www.ukrstat.gov.ua

За останні 5 років темпи зростання середньорічних надоїв на корову суттєво скоротилися у господарствах усіх категорій. Найбільш поширеною породою корів, яка використовується у господарствах усіх категорій є українська чорно-ряба, для якої максимальний надій молока за рік зазвичай не перевищує 7 тис. кг. Відповідно, якщо господарство досягає середньорічних надоїв 5,5-6 тис. кг молока на корову чорно-рябої породи, подальше зростання продуктивності суттєво уповільнюється через біологічні особливості даної породи корів. Для порівняння, середньорічні надої молока на корову голштинської породи можуть перевищувати 10 тис. кг.

Витрати кормів на 1 ц молока в господарствах не перевищують 1 ц. кормових одиниць. 3 початку
2000 р. кормовіддача зросла на третину, що пов'язано із зростанням середньорічних надоїв на корову через удосконалення умов утримання та раціонів годівлі. В балансі молока та молокопродукції спостерігаються негативні тенденції у зв'язку із зниженням обсягів виробництва сировини, скороченням експорту та одночасним збільшенням імпорту молочної продукції. Так за 2017-2019 рр. імпорт молока виріс у 2,5 раза, а експорт скоротився майже на $30 \%$. Фонд споживання молокопродуктів за підсумками 2019 р. становив всього 8,4 млн. т, або близько 200 кг на одну особу за рік в перерахунку на молоко, що на 40 \% менше за рекомендовані раціональні норми споживання.

\section{Таблиця 5}

Баланс молока та молочних продуктів за 2010-2019 рр., тис. т

\begin{tabular}{lccccccc}
\hline \multicolumn{1}{c}{ Показник } & \multicolumn{9}{c}{ Рік } & \multicolumn{2}{c}{2019 p. до } \\
\cline { 2 - 6 } & 2010 & 2015 & 2016 & 2017 & 2018 & 2019 & р., \% \\
\hline Виробництво & 11249 & 10615 & 10382 & 10281 & 10064 & 9663 & 94,0 \\
Зміна запасів (на кінець року) & -11 & -41 & 28 & 33 & 74 & -1 & - \\
Імпорт & 273 & 78 & 105 & 132 & 180 & 337 & 255,3 \\
Усього ресурсів & 11533 & 10734 & 10459 & 10380 & 10170 & 10001 & 96,3 \\
Експорт & 956 & 464 & 434 & 835 & 807 & 593 & 71,0 \\
Витрачено на корм & 1099 & 1097 & 1069 & 1036 & 996 & 969 & 93,5 \\
Втрати & 8 & 15 & 14 & 13 & 12 & 11 & 84,6 \\
Фонд споживання & 9470 & 8995 & 8942 & 8496 & 8355 & 8428 & 99,2 \\
$\quad$ в т.ч. у розрахунку на 1 & 206,4 & 209,9 & 209,5 & 200 & 197,7 & 200,5 & 100,3 \\
\multicolumn{1}{c}{ особу, кг } & & & & & &
\end{tabular}

Джерело: складено на основі http://www.ukrstat.gov.ua

Стратегічною передумовою розвитку молочного скотарства, як і будь-якого іншого напряму аграрного бізнесу $є$ наявність економічного інтересу у зацікавлених суб'єктів господарювання вкладати власні чи запозичені фінансові, матеріально-технічні, а також трудові ресурси в організацію виробництва молока, що проявляється в отриманні економічного ефекту, який формуватиме у виробників інвестиційну ефективність.

Без досягнення очікуваних інвестиційних результатів від виробництва молока, підприємці та господарства населення, що утримують корів і надалі будуть скорочувати поголів'я та виходити із ринку, або переорієнтовуватися на виробництво більш прибуткової продукції, що є цілком закономірним процесом для економіки ринкового типу за умов відсутності ефективної державної політики у даному напрямі тваринництва. Відповідно, державна стратегія розвитку молочного скотарства, на наш погляд, повинна зводитися до впровадження комплексу організаційно- економічних заходів, які дозволять виробникам молока та молочної продукції, а також потенційним інвесторам одержувати необхідний рівень прибутковості, який формуватиме зацікавленість господарюючих суб'єктів виробляти молоко та інвестувати у подальший розвиток свого бізнесу.

За результатами наших досліджень слід виділити п'ять основних економічних передумов зростання виробництва молока, досягнення яких дозволить зупинити спад, що проявляється у скороченні поголів'я корів та обсягів виробництва молока у господарствах та створити сприятливі умови для переходу до фаз піднесення і зростання у молочному скотарстві.

Найважливішою та першочерговою умовою зростання виробництва молока в Україні $є$ встановлення обгрунтованих закупівельних цін на молоко. За роки кризи у молочному скотарстві середні закупівельні ціна на молоко залишаються одними із найнижчих у Європі, у той час, коли роздрібні ціни у поширених торгових мережах станом на 2020 р. наближаються до 
рівня держав Західної Свропи - 1 Євро/л молока. Через низький гатунок близько 80 \% молока, яке надходить в основному від господарств населення, закупівельні ціни в середньому становлять близько 0,17 Євро/кг. Молоко вищого гатунку закуповують по цінах - 0,27 Євро/кг, однак у зв'язку 3 незначною часткою на ринку молока вищого гатунку та наявності переважаючих обсягів молока другого гатунку, середні закупівельні ціни не перевищують 0,2 Євро/кг, що на третину нижче ніж у Польщі.

При собівартості виробництва молока в Україні 0,18 Свро/кг, закупівельні ціни на другий гатунок не можуть забезпечити достатнього економічного ефекту, який стимулюватиме зростання виробництва продукції у господарствах населення, що $\epsilon$ найбільш вагомішим чинником скорочення поголів'я корів у таких господарствах. Для сільськогосподарських підприємств, які виробляють молоко першого, вищого та екстра гатунку умови більш вигідніші. При встановлених закупівельних цінах на молоко підприємства, які виробляють якісну молочну продукцію, за нормативними методами розрахунку собівартості, можуть потенційно досягати чистої рентабельності продажу на рівні $25 \%$ і вище, а рентабельності капіталу $20 \%$, що безумовно $\epsilon$ інвестиційно привабливим, оскільки дисконтований період окупності капіталовкладень, за таких умов складе близько 5-6 років. Також умови, які склалися на ринку для підприємств, що постачають молоко вищих гатунків, сприяють їх розширеному відтворенню. Однак частка молока вищого та екстра гатунку на ринку не перевищує $15 \%$ від усього виробленого, що загалом не сприяє розвитку молочного скотарства. Тому, для зупинення спаду виробництва молока, необхідно забезпечити підвищення закупівельних цін для другого гатунку від господарств населення та підприємств до рівня 0,220,24 Свро/кг молока у базовій жирності на період не менше 5 років. Запропонований рівень закупівельних цін дозволить покрити собівартість виробництва молока та забезпечити одержання мінімального рівня прибутковості, який стане мотивуючим чинником збереження поголів'я корів першочергово у господарствах населення, які формують основу виробничого потенціалу у молочному скотарстві України.

Також, за п’ятирічний період дії підвищених цін, господарства, які виробляють молоко другого гатунку зможуть покращити свій фінансовий стан, заощадити та реінвестувати у розвиток технології виробництва та покращення якості продукції. Підвищення закупівельних цін на молоко для другого гатунку прогнозовано підвищить середній рівень цін до 0,26-0,27 Свро/кг. Проте це не повинно позначатися на роздрібній ціні реалізації молока та молокопродуктів, оскільки рівень оптововідпускних цін від молокопереробних підприємств та роздрібних цін у торгових мережах $є$ суттєво завищений та, на наш погляд, економічно не обгрунтований. Відповідно, розв'язання проблеми раціонального перерозподілу внутрішньогалузевого прибутку, зокрема у молочному скотарстві повинно бути першочерговою економічною передумовою, без досягнення якої неможливо, на наш погляд, зупинити спад виробництва молока та планувати його зростання.

Альтернативним варіантом досягнення раціонального розподілу внутрішньогалузевого прибутку у молокопродуктовому підкомплексі є розвиток конкуренції, особливо на рівні переробки продукції та роздрібної торгівлі. Однією із базових стратегій розвитку для виробників молока повинна стати вертикальна диверсифікація, яка полягає у налагодженні переробки молока власного виробництва на молокопродукти широкого асортименту 3 метою мінімізації ризиків продажу продукції та одержанням вищого рівня доданої вартості. Поширення даної концепції дозволить одержувати вищий рівень прибутку у розрахунку на кожну одиницю використаної молочної сировини та суттєво підвищити вплив виробників молока на кінцеву ціну готового товару.

Наступна економічна передумова полягає у підвищенні впливу виробників молока на роздрібні ціни шляхом розвитку пунктів продажу, спеціалізованих фермерських магазинів на місцевих ринках. Одним із таких успішних прикладів є магазин "ГорбоГори", який знаходиться у м. Пустомити, Львівської області та надає можливість місцевим фермерам реалізовувати власну продовольчу продукцію високої якості, 3 метою задоволення споживчих потреб населення на місцевому ринку. Фермери реалізують готові товари за прямим каналом продажу та за вигідними для себе цінами, а споживач одержую якісну продукцію без посередників за доступною ціною.

Важливою передумовою розвитку молочного скотарства $з$ використанням потенціалу господарств населення $\epsilon$ доступ до фінансових ресурсів, зокрема позикових за пільговими умовами. На наш погляд повинна бути державна програма підтримки доступу виробників молока до банківських цільових кредитів під $1-1,5 \%$, як у багатьох розвинутих державах. Також важливим напрямом вирішення проблеми залучення фінансових ресурсів у молочне скотарство $€$ створення аграрних інвестиційних фондів, які виконуватимуть посередницькі функції щодо залучення коштів від інвесторів та фінансування проєктів зокрема у молочному скотарстві із використанням функціональних онлайн платформ. Суть ідеї полягає у тому, щоб будь-яка зацікавлена особа, в якої є вільні фінансові ресурси, мала можливість на основі посередництва аграрного інвестиційного фонду вкласти кошти на взаємовигідних умовах у розвиток існуючих підприємств, які виробляють молоко, або в створення нових виробництв, $з$ метою одержання інвестиційного доходу.

Також розвиток молочного скотарства, на наш погляд, повинен відбуватися на основі створення сімейних ферм 3 поголів'ям не менше 20 корів при оптовій ціні реалізації молока, а також ферм 3 поголів'ям не менше 9 корів, у тому числі створених на базі уже існуючих особистих селянських господарств при умові організації продажу виробленої продукції за цінами, які наближені до роздрібних, з метою досягнення достатньої суми середньомісячного чистого грошового потоку, що сприятиме формуванню економічного та інвестиційного інтересу, серед працезда- 
тних жителів сільських територій, виробляти молоко (Chemerys et al., 2019).

Важливим чинником зростання виробництва молока $\epsilon$ розвиток системи дорадництва у молочному скотарстві, для інформаційного забезпечення та надання спеціалізованих послуг в економіці, технологіях та ветеринарії щодо ефективної організації виробництва молока, забезпечення необхідних умов утримання корів та контролю за якістю продукції. Система дорадництва досить недооцінена, а іiі потенціал не використовується у повній мірі. Інформація є одним із основних факторів виробництва, що забезпечує конкурентні преваги виробників, в тому числі і у молочному скотарстві. Тому обізнаність в кращих технологіях виробництва молока, догляду за тваринами та економіці молочного скотарства сприятиме розвитку конкурентоспроможних господарств.

Безумовно реалізація запропонованих заходів щодо створення необхідних для зростання виробництва молока економічних передумов потребує значних фінансувань, однак з кожним роком Україна незворотно втрачає галузь молочного скотарства із швидким скороченням поголів'я корів у господарствах усіх категорій. Якщо темпи спаду не зупинити, уже через 10 років Україна з експортера молокопродукції перетвориться в одного із найбільших в Європі імпортера, що створюватиме додатковий тиск на стабільність національної валюти, економічну та продовольчу безпеку держави загалом. Тому у найближчі роки державна політика у молочному скотарстві стикнеться із простим економічним принципом, суть якого можливо описати так: якщо не підтримувати українських виробників, створюючи для них необхідні економічні умови ефективного функціонуванні - будемо вимушені підтримувати закордонних виробників, імпортуючи їхню продукцію.

Для зростання обсягу виробництва молока та формування експортного потенціалу в галузі необхідно розробити державну програму цільової фінансової підтримки розвитку молочного скотарства в господарствах населення, яка повинна забезпечити додатково формування високопродуктивного поголів'я корів чисельністю 1 млн голів, зростання обсягу виробництва молока вищого гатунку на 4,5 млн. т і забезпечення понад 100 тис. сільських жителів додатковим доходом протягом п'яти років (Chemerys et al., 2016).

\section{Висновки}

За результатами дослідження встановлено та обгрунтовано основні економічні передумови зростання виробництва молока в Україні до яких слід віднести встановлення обгрунтованих закупівельних цін на молоко шляхом оптимізації розподілу внутрішньогалузевого прибутку в молокопродуктовому підкомплексі. Розвиток конкуренції, особливо на рівні переробки продукції та роздрібної торгівлі. Підвищення впливу виробників молока на роздрібні ціни шляхом розвитку пунктів продажу, спеціалізованих фермерських магазинів на місцевих ринках. Доступність господарств населення та підприємств до запозичених фінансових ресурсів за пільговими умовами. Створення інвестиційних фондів з використанням функціональних онлайн платформ, зокрема для розвитку молочного скотарства. Розвиток системи дорадництва у молочному скотарстві. Також слід виділити сприяння створенню нових сімейних ферм з виробництва молока на основі господарств населення та їх подальший розвиток до обгрунтованого рівня масштабу не менше 20 корів. Досягнення описаних економічних передумов сприятиме зростанню виробництва молока та молокопродуктів в Україні та підвищенню економічної ефективності функціонування господарств у молочному скотарстві.

Перспективи подальших досліджень. Важливим напрямом досліджень у молочному скотарстві України, на наш погляд, повинно стати інвестиційне забезпечення створення спеціалізованих аграрних підприємств, у тому числі фермерських господарств з виробництва молока, зокрема сімейного типу для забезпечення зростання обсягів виробництва молокопродукції та формування конкурентоспроможного експорту.

\section{References}

Voliak, L., \& Halitska, A. (2018). Analiz vyrobnytstva moloka ta molochnykh produktiv $\mathrm{V}$ Ukraini. Ekonomika i suspilstvo, 19, 1393-1399. doi: 10.32782/2524-0072/2018-19-208 (in Ukrainian).

Kolosha, V. (2018). Problemy formuvannia ta pidvyshchennia ekonomichnoi efektyvnosti vyrobnytstva moloka. Agricultural and Resource Economics: International Scientific E-Journal, 4(4), 99-112. URL: https://are-journal.com/index.php/are/article/view/210 (in Ukrainian).

Rossokha, V., \& Petrychenko, O. (2018). Rozvytok rynku moloka ta molokoproduktsii v Ukraini. Ekonomika APK, 8, 43-54. URL: http://www.eapk.org.ua/ contents/2018/08/43 (in Ukrainian).

Samaichuk, S. (2020). Suchasnyi stan ta perspektyvy rozvytku molochnoho skotarstva $\mathrm{v}$ Khersonskiy oblasti. Efektyvna ekonomika, 5. doi: 10.32702/23072105-2020.5.62 (in Ukrainian).

Chemerys, V., Dushka, V., \& Maksym, V. (2016). Perspektyvni napriamy rozvytku rynku produktsii molochnoho skotarstva. Agricultural and Resource Economics: International Scientific E-Journal, 2(2), 79-91. URL: https://are-journal.com/index.php/are/ article/view/38 (in Ukrainian).

Chemerys, V., Dushka, V., Maksym, V., \& Solomonko, D. (2019). Ekonomichne obgruntuvannia rozvytku simeinykh ferm z vyrobnytstva moloka. NV LNU veterynarnoi medytsyny ta biotekhnolohii. Seriia "Ekonomichni nauky", 21(92), 33-42. doi: 10.32718/nvlvet-e9206 (in Ukrainian).

Cherednichenko, O., \& Pashchenko, O. (2018). Ekonomichni aspekty vyrobnytstva ta spozhyvannia moloka i molochnykh produktiv. Agricultural and Resource Economics: International Scientific EJournal, 4(1), 162-173. URL: https://arejournal.com/index.php/are/article/view/159

(in 
State Statistics Service of Ukraine "Tvarynnytstvo Ukrainy" za 2019 rik [Elektronnyi resurs]. Derzhavna sluzhba statystyky Ukrainy. K., 158. Rezhym dostupu: http://www.ukrstat.gov.ua (in Ukrainian).

State Statistics Service of Ukraine "Balansy ta spozhyvannia osnovnykh produktiv kharchuvannia naselenniam Ukrainy" za 2019 rik [Elektronnyi resurs]. Derzhavna sluzhba statystyky Ukrainy. K., 60. Rezhym dostupu: http://www.ukrstat.gov.ua.

Parzonko, A., \& Bórawski, P. (2020). Competitiveness of Polish dairy farms in the European Union. Agricultural Economics - Czech, 66(4), 168-174. doi: 10.17221/254/2019-AGRICECON.

Michaličková, M., Krupová, Z., Polák, P., Hetényi, L., \& Krupa, E. (2014). Development of competitiveness and its determinants in Slovak dairy farms. Agricultural Economics - Czech, 60(2), 82-88. doi: 10.17221/76/2013-AGRICECON.
Kopeček, P. (2002). Analysis of the yield milk effect on the economics of milk production. Agricultural Economics - Czech, 48(10), 473-479. doi: 10.17221/5355-AGRICECON.

Pieralli, S., Hüttel, S., \& Odening, M. (2017). Abandonment of milk production under uncertainty and inefficiency: the case of western German Farms. European Review of Agricultural Economics, 44(3), 425-454. doi: 10.1093/erae/jbx001.

Sauer, J., \& Latacz-Lohmann, U. (2015) Investment, technical change and efficiency: empirical evidence from German dairy production. European Review of Agricultural Economics, 42(1), 151-175. doi: $10.1093 /$ erae/jbu015. 